\title{
Lubricity additives for motor fuels
}

\section{JEL: L62 DOI: 10.24136/atest.2018.485 \\ Data zgłoszenia: 19.11.2018 Data akceptacji: 15.12.2018}

The paper describes the origin of insufficient lubricity properties of motor fuels, the essence of the problem and laboratory test methods applied to determine fuel lubricity. Ways applied by fuel industry to enhance lubricity are presented. There was also carried out a patent analysis concerning lubricity additives and fuel compositions. The anti-wear behavior of lubricity enhancers, their types and possible undesirable effects were described.

Keywords: lubricity, fuels, lubricity enhancers, boundary lubrication

\section{Introduction}

Since the end of '70s there was observed increased concern about natural environment and also in this period there appeared laws and regulations concerning environmental issues. Some of them forced to reduce pollution of automotive origin because cars are one of the largest sources of air pollutants. The majority of legislative initiatives concerning tailpipe emission was introduced in the ' 80 s. Among others, they concerned reduction of lead content in gasoline as well as sulfur and aromatics in diesel fuel. At that time appeared also such terms as environmentally-friendly fuels, clean burning fuels and reformulated fuels. Automotive fuels are still mostly fossil derived and are complex mixtures containing hundreds of chemical components, mainly hydrocarbons (constituting the bulk of the fuel). They have to satisfy various engine types, different operating conditions and fuel system technologies and to meet efficiency and environmental requirements. Sulfur compounds are naturally occurring constituents of crude oil. They are removed from it in refinery upgrading processes for their odour, acidic nature and the fact that they are known to be strong catalytic poisons. However, severe hydrotreating necessary to remove sulfur produces fuels having poor lubricating ability what, in turns, may lead to failure of the engine injection equipment. Additionally, deterioration of lubricating ability results also from increased injection pressures (ca. 2000-2500 bar) applied in modern engines. To restore lubricity, the refinery industry uses various lubricity additives (called also as: friction modifiers, lubricity enhancers or lubricity improvers)

\section{Lubricity of motor fuels and its evaluation}

Fuel pumps and injection equipment of internal combustion engines are fuel lubricated. No external lubricant is used. Because of very fine tolerances, the moving components operate under boundary lubrication conditions, i.e. there is a very thin film adhering to friction surfaces that reduces friction and prevents wear and failure. Boundary films are formed by physical bonding (van der Waals forces), chemisorption and chemical reactions. Under boundary lubrication conditions the viscosity of lubricant is not a friction controlling parameter. To describe the anti-wear behavior of lubricant it is used a term "lubricity". This term appeared at the end of the 19th century. At that time more popular terms were "oiliness" and "body" introduced by A. Kingsbury [1] to describe differences in lubrication behavior for fluids with the same viscosity and it has been used with reference to mineral oils. "At low speeds, especially under heavy loads, and in all cases where a complete oil film cannot form be- tween the friction surfaces, the viscosity and the oiliness (lubricity, unctuosity) of the lubricant are of great importance "[2].

With the development of science and technology, the term "lubricity" has been modified but there is not established an unequivocal definition of lubricity and its measure. According to R. Marczak [3], lubricity consists of phenomena and processes occurring in the friction zone which depend on the kind of lubricant, solids and atmosphere. Lubricity is not a physical property of a fuel. It is a conventional concept indicating ability to generate boundary layers that protect against excessive wear. As opposed to viscosity, that is an individual property of fuel, lubricity is a complex property - a property of the whole tribological system because it depends on conjunction of phenomena occurring in the friction zone. Lubrication is insufficient when there is a lack of a resistant enough boundary layer able to separate completely surfaces moving against each other.

Problems associated with inadequate fuel lubricity occurred for the first time in the 60 s and were related to injection equipment failures in aircraft engines [4]. Later, during the Vietnam War, users of turbo aircraft engines experienced similar problems. At that time started efforts aimed to develop tests for aircraft fuel lubricity evaluation. First attempts were performed using Dennison tribotester [5] but the obtained results showed poor correlation with field trial results. Many wear tests designed to evaluate lubricants (e.g. Almen, Timken, SAE, four-ball) were applied in search of fuel lubricity test [6]. However, the obtained results did not provide satisfactory results. In 1971 R.T. Aird [4] developed Lucas Dwell Test - the first test dedicated for fuel lubricity evaluation. The method gained some interest in the 1970s, mainly in Great Britain. In the year 1985, J.W. Hadley [7] built the Thornton Aviation Fuel Lubricity Evaluator (TAFLE) by modification of the Amsler machine. TAFLE apparatus has not been widely used because of an expensive and complex procedure but it was successfully applied in individual cases up to 1990s to estimate aviation and diesel fuel lubricity properties [8]. There exists only a prototype of this apparatus. In the late 1960s, the British Ministry of Defense formed a working group to develop a standard method of aviation fuel lubricity evaluation. As a result, the ball-on-cylinder apparatus designed by M. Furey in 1961 [9] was adapted to create the BOCLE test (Ball-on-Cylinder Lubricity Evaluator) [10]. In 1990, after several modifications, the test was accepted as an ASTM standard for measurement of jet fuel lubricity [11].

Diesel fuel as a liquid hydrocarbon-based fuel shows rather poor lubricity properties. However, natural high-sulfur diesel has good lubricity because of the presence of heavier hydrocarbons and trace polar species originated from crude oil. Diesel fuel lubricity problems occurred for the first time in late 80 s. The most stringent regulations regarding the sulfur content were introduced first (1988) in California and then in Sweden and Finland. The amount of sulfur in diesel fuels was reduced from $2000-5000 \mathrm{ppm}$ even up to 10 ppm ((Swedish Class I). High reduction level of sulfur compounds and aromatic hydrocarbons (two- and three-ring mainly) in diesel fuels during hydrotreating was accompanied by reduction of nitrogen- and oxygen-containing polar constituents that were removed as a by-product. Low lubricity diesel fuel causes failure and premature wear of injection equipment - rotary and distributor-type injection pumps which are completely fuel lubricated. To maintain its 
good lubrication quality, the inclusion of lubricity enhancing additives is needed. Attempts to monitor effectiveness of these additives forced researchers to develop appropriate procedures.

As a result of the US Army sponsored study, P.I. Lacey [12] adapted the BOCLE test procedure in order to reproduce the predominant wear mechanisms occurred in fuel injection equipment. The modifications related to the friction couple, test conditions as well as evaluation criteria. The modified procedure is commonly referred as SLBOCLE (Scuffing Load BOCLE) [13]. SLBOCLE is the most popular in the United States where it was accepted as a standard test method for evaluating lubricity of diesel fuels. Another modification of the BOCLE test was done by J.W. Hadley [11] and was called BOCLE (Lubrizol/Hadley) but this procedure is used rarely.

HFRR (High Frequency Reciprocating Rig) - procedure designed to assess diesel fuel lubricity - was developed in 1986 by H.A. Spikes and D. Wei [14]. The procedure was widely practiced after modifications done by $\mathrm{C}$. Bovington [15]. The test consists in high frequency reciprocating motion of a loaded steel ball over a static steel plate immersed in the investigated fuel at the specified test temperature. A measure of diesel fuel lubricity is the value of wear scar diameter corrected to the standardized water vapour pressure of $1.4 \mathrm{kPa}$ and is denoted as WS1,4 (Wear Scar). Generally, the test is performed at $60^{\circ} \mathrm{C}$. Lower test result values reflect better lubricity. Another attempt to monitor diesel fuel lubricity was modification (by Falex) of the well-known four-ball test [16]. The modified version is called BOTD (Ball-on-Three Discs). Attempts to investigate on diesel fuel lubricity were also done by D. Cooper [17] who developed a test procedure based on the Plint TE-77 test rig. Among the existing methods for diesel fuel estimation, the HFRR test is the most popular and the most frequently used.

\section{Fuel lubricity additives}

The worldwide initiatives concerning fuel quality improvement led to limit the sulfur content in transportation fuels up to $10 \mathrm{ppm}$ in Europe (EN 590) and 15 ppm in the United States (ASTM D975). Such deeply desulfurized diesel is called ultra-low sulfur diesel (ULSD). In Europe, ULSD specification started in 2009 (for on-road vehicles) and in 2011 (for non-road vehicles). ULSD fuel requirements in the USA became effective in 2006. At the refinery, ultralow sulfur diesel shows very poor lubricity (typical HFRR wear scar is over $600 \mu \mathrm{m}$ [18]. Such fuel is considered as "dry". To provide good fuel properties, lubricity requirements were introduced into diesel specifications. ASTM accepted HFRR and SL-BOCLE tests and ISO accepted the HFRR method. The maximum HFRR wear scar acceptable by EN 590:2013+A1:2017 is $460 \mu \mathrm{m}$ and by ASTM D975-18 - $520 \mu \mathrm{m}$, although, the Worldwide Fuel Charter recommends $400 \mu \mathrm{m}$ for markets with advanced requirements for emission control [19].

Problems associated with inadequate fuel lubricity may be solved through:

- proper feedstock selection and fuel processing technology in order to maximize the content of constituents having good lubricity properties,

- blending fuel with components having good lubricating characteristics,

- application of lubricity additives.

In practice, the third solution is most often applied by fuel industry. This is also the most cost-effective way. Fuel additives are chemical substances that are added to fuels in order to enhance desirable or to suppress undesirable properties. The global fuel petroleum additive market is growing rapidly to satisfy the demands of more and more stringent quality requirements. From 2007 to
2012 the demand for fuel lubricity additives grew at an above average rate of $3.5 \%$ a year [20]. Lubricity additives are on the market since the early 90 's. The approximate dates of introduction of major fuel additive types are presented in Fig. 1.

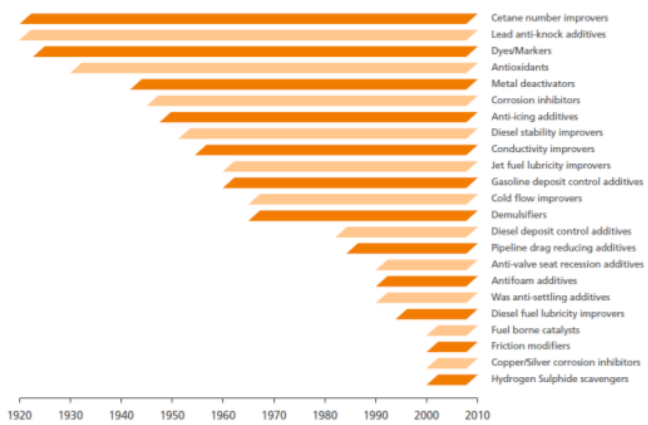

Fig. 1. The approximate dates of introduction of major fuel additive types [21]

Chemical compounds used as fuel lubricity additives have to fulfill the following criteria:

- contain a polar functional group which increases the rate of absorption on metal surfaces,

- contain an olefin chain to provide solubility in the fuel composition,

- ash-forming components are not allowed in their composition,

- do not contain elements acting as catalyst poisons, such as sulfur, phosphorus or boron,

- do not show corrosive action towards the fuelling system,

- do not show negative impact on exhaust emission.

Lubricity additives comprise a range of surface-active chemicals. Generally, they are long chained (usually C12-18) hydrocarbon molecules with small polar functional groups, i.e. with hydrocarbon "tails" and polar "heads". To be effective, the additive molecule should contain a polarity-imparting heteroatom, preferably oxygen. Most commercial lubricity improvers are: carboxylic acids and their salts, amides, alcohols, ethers and esters. Generally, they are classified based on their chemistry as neutral (amides and esters ) or acidic (mono-acidic or dimer acids). Additives, thanks to their affinity, provide bonding to the metal surface and form a protective layer on it (Fig. 2). Polar heads attract to the metal and long hydrocarbon chains are normal to the surface creating a fluid barrier between surfaces. Carboxyl and hydroxyl groups form hydrogen bonds with the metal surface. Film forming ability of esters provide carbonyl groups. Polar groups may be aligned according to their ability to increase lubricity as follows: - $\mathrm{COOH}$ (carboxylic acids) $>\mathrm{CHO}$ (aldehydes) $>\mathrm{OH}$ (alcohols) $>\mathrm{COOCH}_{3}$ (methyl esters) $>\mathrm{C}=\mathrm{O}$ (ketones) $>\mathrm{C}-\mathrm{O}-\mathrm{C}$ (ethers). [22].

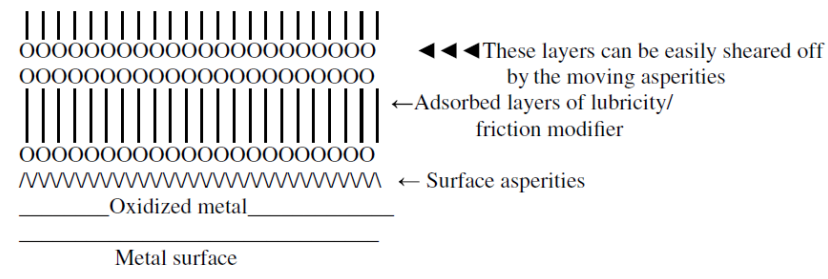

(O: polar head to metal surface)

Fig. 2. Adsorption of a lubricity additive on the metal surface [20]

Better lubricating properties have additives with stronger polarity, higher unsaturation level and those containing more hydroxyl groups in the molecule. The best lubricity enhancer is the carboxyl group [23]. 
Dimer acids were one of the first additives applied to enhance lubricity and were mostly used by aviation industry. However, low sulfur diesel fuel treated with them caused serious problems resulting in filter blockage and pump stopping [24]. There was stated the presence of insoluble carboxylate salts coming from acid-base reactions on the cam plates and shafts. Thus, to avoid such problems dimer acids were subsequently removed from the diesel market. World leading companies producing fuel additives are, among others: Ethyl Petroleum Additives, BASF, Afton , Lubrizol Corporation, Chevron, International Lubricants, Exxon-Chemical, Shell Additives, Adibis, E.I. duPont de Nemours and Company, Nalco Chemical Company, Mobil Chemical Company, Petrolite Corporation, Octel-Starreon.

The carried out patent analysis (Table 1) concerning fuel lubricity additives revealed that, generally, fuel compositions and not individual additives, constitute the majority of patent applications.

Tab. 1. Patent applications concerning fuel lubricity enhancement

\begin{tabular}{|c|c|c|}
\hline Patent number & $\begin{array}{l}\text { Applica- } \\
\text { tiondate }\end{array}$ & Title of patent application \\
\hline US 3273981 & 20.09 .1966 & Anti-wear oil additives. \\
\hline US 5490864 & 13.02.1996 & $\begin{array}{l}\text { Anti-wear lubricity additive for low-sulfur content } \\
\text { diesel fuels. }\end{array}$ \\
\hline EP 0605857 & 13.11.1996 & Mineralische schwefelarme Dieselkraftstoffe. \\
\hline WO 94/17160 & 22.01 .1997 & Fuel composition. \\
\hline JP 09272880 & 21.10 .1997 & Fuel oil composition. \\
\hline PL 174112 & 30.06 .1998 & Miejski olej napędowy. \\
\hline JP 10176175 & 30.06 .1998 & $\begin{array}{l}\text { Additive composition for fuel oil and fuel oil } \\
\text { composition. }\end{array}$ \\
\hline US 5833722 & 10.11.1998 & $\begin{array}{l}\text { Fuel oil compositions with improved lubricity } \\
\text { properties. }\end{array}$ \\
\hline JP 11001692 & 06.01 .1999 & Fuel oil composition. \\
\hline WO 99/00467 & 07.01.1999 & $\begin{array}{l}\text { Fatty acid amide lubricity aids and related } \\
\text { methods for improvement of lubricity of fuels. }\end{array}$ \\
\hline US 5858028 & 12.01.1999 & Fuel oil composition. \\
\hline JP 11071586 & 16.03.1999 & Fuel oil composition for diesel engine. \\
\hline US 6051039 & 18.04 .2000 & Diesel fuel compositions. \\
\hline EP 1013746 & 28.06 .2000 & Fuels with enhanced lubricity. \\
\hline PL 179231 & 31.08 .2000 & Low-sulfur diesel fuel. \\
\hline PL 180044 & 29.12 .2000 & Multifunctional diesel additive. \\
\hline JP 2001049284 & 20.02 .2001 & $\begin{array}{l}\text { Fuel oil lubricity improver and fuel oil composi- } \\
\text { tion. }\end{array}$ \\
\hline EP 1081210 & 07.03.2001 & Fuels with enhanced lubricity. \\
\hline GB 2354254 & 21.03 .2001 & $\begin{array}{l}\text { Fuel composition with improved lubricity perfor- } \\
\text { mance. }\end{array}$ \\
\hline WO 01/36568 & 25.05 .2001 & $\begin{array}{l}\text { Lubricity improver and a fuel and lubricant } \\
\text { composition containing said agent. }\end{array}$ \\
\hline US 6239298 & 29.05 .2001 & Fuel lubricity additives. \\
\hline GB 2357296 & 20.06 .2001 & $\begin{array}{l}\text { Low sulphur fuel composition with enhanced } \\
\text { lubricity. }\end{array}$ \\
\hline WO 01/51592 & 19.07.2001 & Gasoline composition. \\
\hline US 2006/0288638 A1 & 28.12 .2006 & Lubricity additive for fuel. \\
\hline US 2007/0193110 & 23.08 .2007 & Fuel lubricity additives \\
\hline US 2008/0098642 & 01.05 .2008 & $\begin{array}{l}\text { Lubricity improving additive composition for low } \\
\text { sulfur diesel fuel. }\end{array}$ \\
\hline US 2009/0056203 A1 & 05.03.2009 & $\begin{array}{l}\text { Branched carboxylic acids as fuel lubricity } \\
\text { additives. }\end{array}$ \\
\hline US 2010/0000484 A1 & 07.01 .2010 & Liquid fuel compositions. \\
\hline US 8,518,128 B2 & 27.08 .2013 & Fuel additive composition improve fuel lubricity. \\
\hline PCT/FR2016/052168 & 02.09 .2016 & Lubricity additive for fuel with a low sulfur content. \\
\hline US 9476005 B1 & 25.10 .2016 & High-performance diesel fuel lubricity additive. \\
\hline US 9,745,531 B2 & 29.08 .2017 & Fuel lubricity additive. \\
\hline US 2018/0187110 A1 & 05.07 .2018 & $\begin{array}{l}\text { Lubricity additive for fuel with a low sulphur } \\
\text { content. }\end{array}$ \\
\hline US 9,745,531 B2 & 29.08 .2017 & Fuel lubricity additive. \\
\hline US 2018/0127675 & 10.052018 & $\begin{array}{l}\text { Dialkylaminoalkanol friction modifiers for fuels } \\
\text { and lubricants. }\end{array}$ \\
\hline
\end{tabular}

Choosing a fuel lubricity additive one should take into consideration mostly: effectiveness, cost and no-harm performance. Although one chemical improves some fuel characteristic, it may deteriorate the other ones or influence negatively engine operation. Thus, addition of an additive in the fuel should be carefully analysed [25]. Generally, lubricity enhancers do not influence negatively the engine exhaust emission. However, some diesel lubricity additives were reported to react with crankcase lubricating oil. In result, sticky carbonaceous deposits on plunger surfaces were detected [26]. Another negative effect may result from sodium contamination of diesel fuel. sodium hydroxide and a fuel soluble salt - sodium 2ethylhexanote interact with mono-acid lubricity additives producing filter blocking and injector sticking [27].

To be effective in wear reduction, lubricity additives have to be mixed with the fuel at proper concentration. Fuel lubricity additive treat levels are generally low, in most cases from 20 up to 200 ppm. At the level over 500 ppm, the additive effectiveness usually decreases. Fig. 3. presents the HFRR scar diameter reduction with the "treat rate" of an additive [28]. At low concentrations (region I), the surface is incompletely covered by adsorbed additive particles which do not support anti-wear action. Increased additive concentration (in the region II) results in wear lowering due to formation of a coherent but still incomplete film. At certain additive concentration (transition point from the region II to the region III) the boundary layer is complete and protects the surface against wear. Further increase in concentration does not reduces the wear scar diameter.

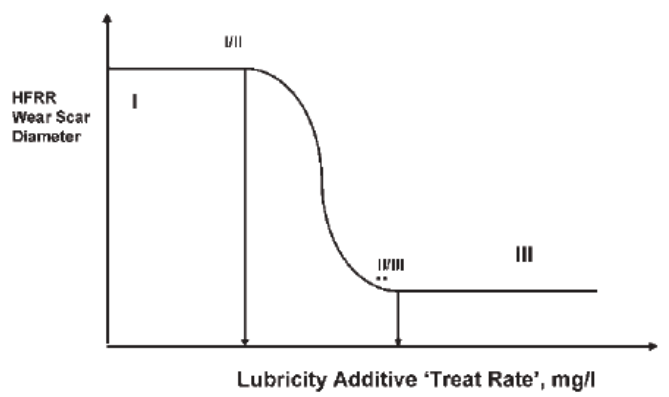

Fig. 3. Effect of lubricity additive concentration on wear reduction [28]

Another way to restore diesel fuel lubricity is blending it with high lubricity fuel. The most common practice is blending low sulfur diesel with commercial biodiesel (vegetable oil or animal fat based diesel fuel, consisting of long-chain mono-alkyl esters), usually at a level of $1-2 \%$. $[29,30]$. Biodiesel possess very good lubricating properties because its main constituents are neat fatty esters. Additionally, biodiesel contains also minor constituents (usually considered undesirable) formed during the transesterification reaction, such as neat free fatty acids, monoacylglycerols and glycerol. These constituents possess better lubricity than neat esters because of their free $\mathrm{OH}$ groups [31]. The required biodiesel level exceeds the typical additive level but this does not create problems because biodiesel properties are compatible with petrodiesel. However, some problems may arise if the blends would take up water. Since the saturation level of moisture in biodiesel is 15-25 times higher than that of petrodiesel (in the range of $4-35^{\circ} \mathrm{C}$ ) and diesel fuel lubricity decreases linearly with the moisture content, this issue should be avoided [32].

Lubricity problems concern also gasoline $[33,34]$ and became more urgent with the development of direct injection because high injection pressures and low lubricity may lead to the failure of injection equipment.

\section{Summary}

Severe hydrotreatment technologies are applied by the petroleum industry to remove sulfur compounds from automotive fuel base stock. However, desulfurization removes also heavier hydrocarbons and trace polar species originated from crude oil what results in a deterioration of lubricity properties. One of the most commonly applied method to meet fuel specification and restore fuel lubricity is application of lubricity additives i.e. surface-active compounds (long 
chained hydrocarbon molecules with small polar functional groups) added to the fuel base stock during final blending. Additives provide sufficient boundary layer lubrication. They may be acidic or neutral. Mostly applied are mono-carboxylic acids and esters. One of the most important feature of lubricity additives is their no-harm performance. Interaction with other fuel components should be carefully analysed to prevent adverse side effects.

\section{Bibliography:}

1. Kingsbury A., A new oil-testing machine and some of its results, Trans ASME 1903; Vol. 24:143-160.

2. Archbutt L., Deeley R.M., Lubrication and lubricants. Charles Griffin \& Company, London 1900. 451p.

3. Marczak, R., Tribological properties of bearing materials. Thesis presented to qualify as assistant professor. Informator WITPIS 21/77, 1977 (in Polish).

4. Aird R.T., Forgham S.L., The lubricating quality of aviation fuels, Wear 1971, Vol. 18, p. 361-380.

5. Fuel lubricity. Interim report on the work of the Ministry of Aviation Fuel Supply (MAS), Fuel Lubricity Panel. Rep. AX/395/014, 1971 (Ministry of Aviation).

6. Appeldoorn J., Dukek W., Lubricity of Jet Fuels, SAE Technical Paper 660712, 1966.

7. Hadley J.W., A method for the evaluation of the boundary lubricating properties of aviation turbine fuels, Wear 1985, Vol. 101, p. 219-253.

8. Tucker R.F., Stradling R.J., Wolveridge P.E., Rivers K.J., Ubbens A., The lubricity of deeply hydrogenated diesel fuels - the Swedish experience, SAE Paper 942016, Diesel fuel: additives and performance, Warrendale, PA, SAE, p. 1617-1633.

9. Furey M.J., Metallic contact and friction between sliding surfaces, ASLE Transactions 1961, Vol. 4, p. 1-11.

10. Tao F.F., Appeldoorn J.K, The ball-on-cylinder test for evaluating jet fuel lubricity, ASLE Transactions 1968, Vol. 11, p. 345352.

11. Hadley J.W., Blackhurst P., An appraisal of the ball-on-cylinder technique for measuring aviation turbine fuel lubricity, Lubrication Engineering 1991, Vol. 47, No. 5, p. 404-411.

12. Lacey P.I., Development of a lubricity test based on the transition from boundary lubrication to severe adhesive wear in fuels, Lubrication Engineering 1994, Vol. 507, No. 10, p. 749-757.

13. Lacey P.I., Westbrook S.R., Diesel fuel lubricity, 1995 SAE Transactions, Journal of Fuels \& Lubricants, Paper 950248, p. 214-225.

14. Wei D., Spikes H.A., The lubricity of diesel fuels, Wear 1986, Vol. 111, p. 217-235.

15. Bovington C., Caprotti R., Meyer K., Spikes H.A., Development of a laboratory test to predict lubricity properties of diesel fuels and its application to the development of highly refined fuels, Tribotest 1995, Vol. 2, No. 2, p. 93-112.

16. www.falexint.com

17. Cooper D., Laboratory screening tests for low sulfur diesel fuel lubricity, Lubrication Science 1995, Vol. 7, No. 2, p. 133-148.

18. Spicer A.D., Diesel fuel lubricity additives study results. The Diesel Place \& A.D. Spicer, August 2007.

19. Fifth Edition of the Worldwide Fuel Charter, September 2013.

20. Srivastava S. P., Hancsók J., Fuels and fuel-additives, John Wiley \& Sons, Inc., Hoboken, New Jersey 2014, 364 p.

21. Fuel additives. Use and benefits. ATC Document 113, September 2013.
22. Knothe G., Steidley K.R., Lubricity of components of biodiesel and petrodiesel: The origin of biodiesel lubricity, Energy \& Fuels 2005, Vol. 19, No. 3, p. 1192-1200.

23. Agarwal S.,. Chhibber V.K., Bhatnagar A.K., Tribological behavior of diesel fuels and the effect of anti-wear additives, Fuel 2013, Vol. 106, p. 21-29

24. Claydon D., The use of lubricity additives to maintain fuel quality in low sulphur diesel fuel, Goriva i maziva, 2014, Vol. 53, p. 342-353.

25. Batt R.J., McMillan J.A., Bradbury I.P., Lubricity additives Performance and no-harm effects in low sulfur fuels, 1996 SAE Transactions, Journal of Fuels \& Lubricants, Paper 961943, p. 1380-1388.

26. Mikkonen, S. Tenhunen, E., Deposits in diesel fuel-injection pumps caused by incompatibility of fuel and oil additives" SAE Technical Paper 872119, 1987.

27. Barker J., Cook S., Richards P., Sodium contamination of diesel fuel, its interaction with fuel additives and the resultant effects on filter plugging and injector fouling, SAE Int. Journal of Fuels and Lubrication 2013, Vol. 6, Issue 3, p. 826-838.

28. Fox M.F., Development of the diesel fuel additive lubricity model, Proc. IMechE 2007, Vol. 221 Part J: J. Engineering Tribology, p. 161-164.

29. Sukjit E., Dearn K.D., Tsolakis A., Interrogating the surface. The effect of blended diesel fuels on lubricity, SAE Int. Journal of Fuels and Lubricants 2012, Vol. 5, No.1, p. 154-162.

30. Muñoz M., Moreno F., Monné C., Morea J., Terradillos J., Biodiesel improves lubricity of new low sulphur diesel fuels, Renewable Energy 2011, Vol.36, No.11, p.2918-2924.

31. Knothe G., Razon L.F., Biodiesel fuels, Progress in Energy and Combustion Science 2017, Vol. 58, p. 36-59.

32. Lapuerta M., Sánchez-Valdepeñas J., Sukjit E., Effect of ambient humidity and hygroscopy on the lubricity of diesel fuels, Wear 2014, Vol. 309, Issues 1-2, 2014, p. 200-207.

33. Wei D.P., Spikes H.A., Korcek S., The lubricity of gasoline, Tribology Transactions 1999, Vol. 42, p. 813-823.

34. Hsieh P.Y., Bruno T.J., A perspective on the origin of lubricity in petroleum distillate motor fuels, Fuel Processing Technology 2015, Vol. 129, p. 52-60.

\section{Dodatki smarnościowe do paliw silnikowych}

W artykule opisano geneze problemu smarności paliw silnikowych, jego istotę oraz metody badania właściwości smarnych. Przedstawiono sposoby podwyższania smarności paliw stosowane w przemyśle petrochemicznym. Dokonano również analizy literatury patentowej w tym zakresie. Omówiono mechanizm działania dodatków smarnościowych, ich rodzaje oraz możliwe działania niepożądane.

Słowa kluczowe: smarność, paliwa, dodatki smarnościowe, tarcie graniczne

Autorzy:

dr Małgorzata Wojtyniak - Uniwersytet Technologiczno - Humanistyczny im. Kazimierza Pułaskiego w Radomiu,

m.wojtyniak@uthrad.pl

dr inż. Wiesław Olszewski - Uniwersytet Technologiczno Humanistyczny im. Kazimierza Pułaskiego w Radomiu,

w.olszewski@uthrad.pl

mgr inż. Grzegorz Wronka - Uniwersytet Technologiczno Humanistyczny im. Kazimierza Pułaskiego w Radomiu 